\title{
Helicobacter pylori Infection and Gastric Microbiota
}

\author{
Gokben Ozbey ${ }^{1}$, Emma Sproston ${ }^{2}$, Alfizah Hanafiah ${ }^{3}$
}

\begin{abstract}
Owing to its strong acid production, the stomach was known to be a bacteria-free organ for many years. On the other hand, the presence of Helicobacter pylori (H. pylori) and other acid-resistant microbiota that are to persist in the stomach challenged this. It is now recognized that the existence of $H$. pylori and non-H. pylori species have been linked to the improvement of gastric disease; despite this, there is little published data on the interaction of gastric bacterial flora and the resultant effect on gastric health. The stomach has a unique microbiota including five major phyla, such as Firmicutes, Proteobacteria, Actinobacteria, Fusobacteria and Bacteroidetes. These phyla are identified in both $\mathrm{H}$. pylori-infected and uninfected persons. The resident gastric microflora may mediate the role of $H$. pylori in the gastric diseases. This article aims to review previous studies that examine the impact of $H$. pylori infection and the effect of resident gastric microbiota on gut health and disease conditions. Keywords: Gastric microbiota, Helicobacter pylori, Stomach.

Euroasian Journal of Hepato-Gastroenterology (2020): 10.5005/jp-journals-10018-1310
\end{abstract}

\section{BACKGROUND}

The compound of human gastrointestinal microbiota tract has been well studied and a number of reports explaining the relationships between the diversity of microbiota in the human gastrointestinal tract and its influence on health and disease have been conducted. ${ }^{1,2}$ The human gut microbiota includes about 100 trillion microbial substances comprising of many archaea, bacteria and viruses. ${ }^{3}$ The development of the intestinal microbiome during the early stages of life affects the improvement of the mucosal immune system and an individual's susceptibility to some diseases. ${ }^{3}$ The gastric was known to be a sterile organ owing to its strong acid production; however, the discovery of Helicobacter pylori (H. pylori) in 1982 followed by additional microbiota being identified in the stomach changed this notion. ${ }^{4}$ Interest and research in the stomach's microbial community has expanded in recent years due to improvements in culture-independent methods. ${ }^{5}$

Helicobacter pylori is a microaerophilic gram-negative bacteria with spiral shaped and placed within the order of Campylobacterales. ${ }^{6}$ It is a major human gastric pathogen that resides in more than $50 \%$ of the world's population. ${ }^{6}$ Although more than $80 \%$ of the infected people remain asymptomatic, in others it is capable of developing several gastric diseases such gastric cancer, peptic ulcers and chronic gastritis. ${ }^{8,9}$ In the Elazig Province of East of Turkey, the prevalence of $H$. pylori infection was $76.1 \%$ in adults and $66.3 \%$ in children. ${ }^{10,11}$ It was thought that the existence of $H$. pylori in the stomach inhibited the colonization of other non- $H$. pylori bacterial flora. ${ }^{1}$ Nevertheless, recent studies have reported a wider image of the gastric microbiota that is not limited to H. pylori. ${ }^{12,13}$

\section{Gastric Microbiota in Association with H. pylori Infection}

Although non-H. pylori species have been related to the improvement of gastric disorders, the published information on the gastric bacterial flora are very limited. ${ }^{14}$ Detection of the gastric microbiota is often dependent on the cultivation of gastric juice or mucosal biopsies ${ }^{15}$ where reports have detected several genera of the Actinobacteria, Firmicutes, Fusobacteria, and Proteobacteria, as well as yeasts. ${ }^{16,17}$

\begin{abstract}
1'Department of Medical Services and Techniques, Vocational School of Health Services, Firat University, Elazig, Turkey

${ }^{2}$ Department of Biology and Biochemistry, School of Biological Sciences, University of Aberdeen, Aberdeen, United Kingdom

${ }^{3}$ Department of Medical Microbiology and Immunology, Faculty of Medicine, Universiti Kebangsaan Malaysia, Kuala Lumpur, Malaysia
\end{abstract}

Address reprint requests to: Gokben Ozbey, Department of Medical Services and Techniques, Vocational School of Health Services, Firat University, Elazig, Turkey, Phone: +904242370000-6535, e-mail: gokben.ozbey@yahoo.com

How to cite this article: Ozbey G, Sproston E, Hanafiah A. Helicobacter pylori Infection and Gastric Microbiota. Euroasian J Hepato-Gastroenterol 2020;10(1):36-41.

Source of support: Nil

Conflict of interest: None

The gastric microbiota in a healthy population has a similar compound at both the genera level and phyla irrespective of geographical area and ethnicity. ${ }^{1,5}$ Recent advances have shown that the gastric microbiota composition is diverse in $\mathrm{H}$. pyloriinfected and uninfected individuals. However, certain genera were at higher proportion in $\mathrm{H}$. pylori-infected individuals. ${ }^{12}$ In contrast to this, Bik et al. ${ }^{18}$ suggested that no statistically significant discrepancy in the diversity of gastric microbiota between $H$. pylori positive and negative patients was found. However, in this study, 7 H. pylori-uninfected individuals identified by traditional methods were actually had $H$. pylori-positive results when tested using the DNA-based techniques. ${ }^{18}$ Others have reported inconsistent properties of gastric microbiota in $\mathrm{H}$. pylori-positive patients ${ }^{21}$ (Table 1).

For H. pylori-negative subjects, a highly different gastric microbiota was present that included the 5 major phyla: Actinobacteria, Firmicutes, Bacteroidetes, Fusobacteria, and Proteobacteria; these studies used PCR and sequence-based techniques. ${ }^{18,19,22}$ In strong agreement, the sequencing of 1,833 bacterial isolates obtained from gastric biopsies of 23 healthy adults also exhibited the same 5 major phyla. These came from a highly diverse bacterial community totaling 128 phylotypes

(0) The Author(s). 2020 Open Access This article is distributed under the terms of the Creative Commons Attribution 4.0 International License (https://creativecommons. org/licenses/by-nc/4.0/), which permits unrestricted use, distribution, and non-commercial reproduction in any medium, provided you give appropriate credit to the original author(s) and the source, provide a link to the Creative Commons license, and indicate if changes were made. The Creative Commons Public Domain Dedication waiver (http://creativecommons.org/publicdomain/zero/1.0/) applies to the data made available in this article, unless otherwise stated. 
Table 1: Distribution of gastric microbiota in humans

\begin{tabular}{|c|c|c|c|c|}
\hline Country & $\begin{array}{l}\text { Study } \\
\text { population } \\
\text { (number of } \\
\text { subjects) }\end{array}$ & $\begin{array}{l}\text { Type of samples, } \\
\text { method }\end{array}$ & Distribution of gastric microbiota & References \\
\hline $\begin{array}{l}\text { United } \\
\text { States }\end{array}$ & $\begin{array}{l}23 \text { adults }(13 \\
\text { Caucasians, } \\
5 \text { Hispanics, } \\
\text { and } 5 \text { African } \\
\text { Americans) }\end{array}$ & $\begin{array}{l}\text { Gastric biopsies, } 16 \mathrm{~S} \\
\text { rDNA clone library }\end{array}$ & $\begin{array}{l}\text { Overall gastric microbiota: } \\
\text { Proteobacteria (952 clones) } \\
\text { Firmicutes (464 clones) } \\
\text { Bacteroidetes (193 clones) } \\
\text { Actinobacteria ( } 164 \text { clones) } \\
\text { Fusobacteria (56 clones) } \\
\text { Top } 5 \text { genera: } \\
\text { Streptococcus ( } 299 \text { clones) } \\
\text { Prevotella (139 clones) } \\
\text { Rothia ( } 95 \text { clones) } \\
\text { Fusobacterium ( } 45 \text { clones) } \\
\text { Veillonella (41 clones) } \\
\text { No. of phylotypes: } \\
\text { HP+ve = } 60 \text { phylotypes } \\
\text { HP-ve = } 143 \text { phylotypes }\end{array}$ & Bik et al. ${ }^{18}$ \\
\hline Sweden & $\begin{array}{l}6 \text { adults } \\
\text { (healthy } \\
\text { individuals) }\end{array}$ & $\begin{array}{l}\text { Gastric biopsies, } \\
454 \text { pyrosequencing }\end{array}$ & $\begin{array}{l}\text { HP-ve }=262 \text { phylotypes: } \\
\text { Most prominent phylotypes were Streptococcus, Actinomyces, } \\
\text { Prevotella, Gemella } \\
\mathrm{HP}+\mathrm{ve}=93-97 \% \text { of the reads belong to Proteobacteria }\end{array}$ & $\begin{array}{l}\text { Andersson } \\
\text { et al. }{ }^{19}\end{array}$ \\
\hline Sweden & $\begin{array}{l}6 \text { gastric } \\
\text { cancer }\end{array}$ & $\begin{array}{l}\text { Gastric biopsies, } \\
\text { T-RFLP, } 16 \mathrm{~S} \text { rRNA } \\
\text { cloning and } \\
\text { sequencing }\end{array}$ & $\begin{array}{l}102 \text { phylotypes were identified including } 5 \text { phyla: } \\
\text { Firmicutes (61\% relative abundance) } \\
\text { Bacteroidetes ( } 11 \% \text { relative abundance) } \\
\text { Actinobacteria ( } 7 \% \text { relative abundance) } \\
\text { Proteobacteria ( } 6 \% \text { relative abundance) } \\
\text { Fusobacteria (3\% relative abundance) } \\
\text { Highly presented genera: } \\
\text { Firmicutes: Streptococcus, Lactobacillus, Veillonella, Prevotella } \\
\text { Bacteroidetes: different species of Prevotella } \\
\text { Proteobacteria: alpha-, beta-, gamma-, delta-, and } \\
\text { Epsilonproteobacteria, Neisseria, Haemophilus }\end{array}$ & $\begin{array}{l}\text { Dicksved } \\
\text { et al. }^{20}\end{array}$ \\
\hline Chinese & $\begin{array}{l}10 \text { adults } \\
\text { ( } 5 \text { normal, } \\
5 \text { gastritis) }\end{array}$ & $\begin{array}{l}\text { Gastric biopsies, } \\
\text { Cloning and } \\
\text { sequencing of } \\
16 \mathrm{~S} \text { rRNA }\end{array}$ & $\begin{array}{l}\text { Clone percentage from normal and gastritis biopsies (average): } \\
\text { Firmicutes: } 22 \% \text { in normal, } 41 \% \text { in gastritis } \\
\text { Proteobacteria: } 37 \% \text { in normal, } 20 \% \text { in gastritis } \\
\text { Bacteroidetes: } 28 \% \text { in normal, } 25 \% \text { in gastritis } \\
\text { Actinobacteria: } 8 \% \text { in normal, } 8 \% \text { in gastritis } \\
\text { Fusobacteria: } 4 \% \text { in normal, } 6 \% \text { in gastritis } \\
\text { Overall top } 5 \text { genera: } \\
\text { Streptococcus ( } 254 \text { clones) } \\
\text { Prevotella ( } 243 \text { clones) } \\
\text { Neisseriae (175 clones) } \\
\text { Haemophilus ( } 122 \text { clones) } \\
\text { Porphyromonas ( } 68 \text { clones) }\end{array}$ & Li et al. ${ }^{21}$ \\
\hline $\begin{array}{l}\text { Puerto Rica, } \\
\text { Venezuela, } \\
\text { and United } \\
\text { States }\end{array}$ & $\begin{array}{l}12 \text { adults (10 } \\
\text { Amerindians, } \\
2 \text { immigrants } \\
\text { to the United } \\
\text { States) }\end{array}$ & $\begin{array}{l}\text { Gastric biopsies, } \\
\text { PhyloChip (DNA } \\
\text { microarray) }\end{array}$ & $\begin{array}{l}\text { Phyla identified in HP+ve }(n=8) \text { : } \\
\text { Proteobacteria (classes Alpha, Delta, Epsilonproteobacteria) } \\
\text { Acidobacteria } \\
\text { Spirochaetae } \\
\text { Phyla identified in HP-ve }(n=4) \text { : } \\
\text { Actinobacteria } \\
\text { Firmicutes } \\
\text { Bacteroidetes }\end{array}$ & $\begin{array}{l}\text { Maldonado- } \\
\text { Contrerase } \\
\text { et al. }{ }^{22}\end{array}$ \\
\hline
\end{tabular}




\begin{tabular}{|c|c|c|c|c|}
\hline Country & $\begin{array}{l}\text { Study popula- } \\
\text { tion (number of } \\
\text { subjects) }\end{array}$ & $\begin{array}{l}\text { Type of samples, } \\
\text { method }\end{array}$ & Distribution of gastric microbiota & References \\
\hline & & & Fusobacteria & \\
\hline & & & Proteobacteria (classes Beta and Gammaproteobacteria) & \\
\hline \multirow[t]{5}{*}{ Chinese } & \multirow{5}{*}{$\begin{array}{l}103 \text { patients } \\
\text { with dyspeptic } \\
\text { symptoms }\end{array}$} & \multirow[t]{5}{*}{$\begin{array}{l}\text { Gastric biopsies, } \\
\text { MALDI-TOF MS }\end{array}$} & $\begin{array}{l}\text { In } 65 \% \text { of HP+ve patients, } 201 \text { non-HP bacterial isolates were } \\
\text { identified. The dominant species were: }\end{array}$ & \multirow[t]{5}{*}{ Hu et al. ${ }^{14}$} \\
\hline & & & Streptococcus & \\
\hline & & & Neisseria & \\
\hline & & & Rothia & \\
\hline & & & Staphylococcus & \\
\hline \multirow[t]{9}{*}{ Spain } & \multirow{9}{*}{$\begin{array}{l}12 \text { healthy } \\
\text { persons }\end{array}$} & \multirow{9}{*}{$\begin{array}{l}\text { Gastric biopsies } \\
\text { and gastric juice, } \\
\text { Culture nested PCR } \\
\text { pyrosequencing of } \\
\text { 16S rRNA }\end{array}$} & Most abundant phylum: & \multirow{9}{*}{$\begin{array}{l}\text { Delgado } \\
\text { et al. }^{5}\end{array}$} \\
\hline & & & Firmicutes & \\
\hline & & & Proteobacteria & \\
\hline & & & Actinobacteria & \\
\hline & & & 4 main genera identified: & \\
\hline & & & Propionibacterium & \\
\hline & & & Lactobacillus & \\
\hline & & & Streptococcus & \\
\hline & & & Staphylococcus & \\
\hline \multirow[t]{3}{*}{ Korean } & \multirow{3}{*}{$\begin{array}{l}31 \text { patients (11 } \\
\text { noncardia GC, } \\
10 \text { intestinal } \\
\text { metaplasia, } \\
10 \text { chronic } \\
\text { gastritis) }\end{array}$} & \multirow{3}{*}{$\begin{array}{l}\text { Gastric biopsies, } 454 \\
\text { pyrosequencing }\end{array}$} & Dominant phyla identified: & \multirow[t]{3}{*}{ Eun et al. ${ }^{23}$} \\
\hline & & & Chronic gastritis-Epsilonproteobacteria (contain H. pylori) & \\
\hline & & & Gastric cancer—Bacilli (Streptococci and Lactobacilli) & \\
\hline \multirow[t]{6}{*}{ Spain } & \multirow[t]{6}{*}{51 children } & \multirow{6}{*}{$\begin{array}{l}\text { Gastric biopsies, V4- } \\
16 \mathrm{~S} \text { ribosomal RNA } \\
\text { gene high-throughput } \\
\text { sequencing }\end{array}$} & HP+ve $(n=18):$ & \multirow[t]{6}{*}{ Llorca et al. ${ }^{24}$} \\
\hline & & & Higher abundance of Helicobacter genus (66.3\%) & \\
\hline & & & Abundant of Epsilonproteobacteria & \\
\hline & & & HP-ve $(n=33)$ : & \\
\hline & & & $0.45 \%$ Helicobacter genus & \\
\hline & & & Abundant of gamma- and betaproteobacteria & \\
\hline
\end{tabular}

from 8 bacterial phyla. ${ }^{18,25}$ The gastric microbiome in H. pylorinegative subjects was mostly predominated by the same phylum, however, with diverse percent abundances: with $52.6 \%$ of Proteobacteria, $26.4 \%$ of Firmicutes, $12 \%$ of Bacteroidetes and $6.4 \%$ of Actinobacteria. ${ }^{24}$ In other studies, the most abundant phyla of Firmicutes, Bacteroidetes, and Actinobacteria were found in H. pylori-negative subjects. ${ }^{26}$ The common genera observed in H. pylori-negative individuals includes Gemella, Prevotella, and Streptococcus. ${ }^{19}$

Like $H$. pylori-negative individuals, $H$. pylori-positive humans' stomach were also abundant with Proteobacteria, Firmicutes, and Actinobacteria. ${ }^{19}$ However, in samples from $3 \mathrm{H}$. pylori-positive individuals, H. pylori was the dominant species and accounted for more than $90 \%$ of all sequence reads using 454 pyrosequencing technology. ${ }^{19}$ Here, only 33 phylotypes were identified, which was 229 fewer than were found in $H$. pylori-negative individuals ${ }^{19}$ This suggests that $H$. pylori-colonized individuals harbor a significantly lower diversity of gastric microbiota and may suggest some inhibitory effects on the colonization of non-H. pylori gastric bacteria. This is also suggested in other studies where $H$. pylori dominates the gastric microbiota and results in a reduced bacterial diversity. The $H$. pylori eradication yielded a restoration of microbiota in the gastric environment where the abundance of Helicobacter in pretreatment and posttreatment was 83.7 and $6.88 \%$, respectively, and the relative abundance of non- $H$. pylori Proteobacteria raised from 4.55 to $51.7 \% .{ }^{27}$ It also appears that the relative abundance changes with Proteobacteria, Spirochaetes, and Acidobacteria increasing, and Actinobacteria, Bacteroidetes, and Firmicutes decreasing in H. pylori-positive individuals. ${ }^{28} \mathrm{~A}$ total of 44 phyla were identified from 12 corpus biopsy samples from $8 \mathrm{H}$. pylori-positive individuals with the most common being Proteobacteria, Firmicutes, Actinobacteria, and Bacteroidetes. ${ }^{22}$ This was performed using high-density 16S rRNA gene microarray (PhyloChip). ${ }^{22}$ Again and in agreement with the above study, the relative abundance of Acidobacteria, Proteobacteria, and Spirochaetes increased while Actinobacteria, Bacteroidetes, and Firmicutes decreased in H. pylori-positive samples. In H. pylori-positive pediatric patients, the major phylum were Proteobacteria (69.3\%), Firmicutes (14.3\%), Bacteroidetes (8.2\%), and Actinobacteria (6\%). ${ }^{29}$ The higher percentage of Proteobacteria is likely to be due to the presence of Helicobactergenus in these samples. It has also been shown that the compound of microbiota between $\mathrm{H}$. pylori-negative controls and $H$. pylori positive individuals were diversities in the total number of anaerobes and clostridia. ${ }^{30}$

\section{Gastric Microbiota Compositions in Patients with Gastric Diseases}

The above highlights the alterations in the microbiota composition in relation to the infection with $\mathrm{H}$. pylori. ${ }^{31}$ Below we discuss the compound of the gastric microbiota in $H$. pylori-infected and 
uninfected patients with gastric disorders (e.g. peptic ulcer, chronic gastritis, and gastric cancer). ${ }^{31}$

A study by Eun et al. ${ }^{23}$ suggested that differences exist in the compound of gastric microbiota in people with chronic gastritis, precancerous lesions and gastric cancer. The same authors also reported that the gastric flora may also partially influence the impact of $H$. pylori infection in carcinogenesis. ${ }^{23}$ Diversities in the gastric microbiota in healthy individuals are unlikely to be due to ethnicity or geographical region because these factors have been shown to have a similar gastric microbiota composition. ${ }^{1}$

\section{Chronic Gastritis}

In H. pylori-positive individuals with antral gastritis, the abundancy of phyla Proteobacteria was decreased and Firmicutes was increased compared to $H$. pylori-negative subjects. ${ }^{21}$ In patients with atrophic gastritis, Streptococcus increased whilst Prevotella decreased when compared to healthy subjects. ${ }^{1}$ In addition, those with chronic gastritis showed a higher rate of bacterial growth than individuals not having gastritis. ${ }^{12}$ This was performed on gastric samples from 50 individuals having chronic gastritis and 53 samples without chronic gastritis. ${ }^{12}$ By using matrix assisted laser desorption ionization-time of flight (MALDI-TOF), the species that were significantly associated with gastritis from mucosa samples were H. pylori, Streptococcus mitis, Neisseria flavencens, and Nieseria perlava and species associated with gastritis from gastric juice samples were $S$. oralsi, Rothia mufilaginosa, and Nieseria perlava. ${ }^{12}$ The dominant species associated with gastritis such as Neisseria, Rothia, Staphylococcus and Streptococcus were identified and varied from the acid resistant bacterial species as indicated earlier in healthy individuals. ${ }^{14,32}$

\section{Peptic Ulcer Disease}

A study demonstrated that despite being no significant differences between uninfected and $H$. pylori-infected persons, the isolation of streptococci was related to the presence of peptic ulcers. ${ }^{33}$ This analysis was performed using molecular methods such as MALDI-TOF MS biotyping and 16S rRNA sequencing on samples obtained from 215 Malaysian patients. ${ }^{33}$ In China the common species identified from $H$. pylori-positive gastric biopsy specimens were Streptococcus, Neisseria, Rothia, and Staphylococcus using the MALDI-TOF MS technique. ${ }^{14}$ These isolated bacteria are more acid-susceptible and differed from $H$. pylori-negative volunteers. In addition, the $H$. pylori-positive individuals with gastric ulcers, a much lower prevalence of non-H. pylori species were identified compared to those with nonulcer dyspepsia. ${ }^{14}$

\section{Gastric Cancer}

Gastric cancer has various risk factors which includes $H$. pylori infection, host genetic and environmental factors. H. pylori infection is a well-studied risk factor for gastric adenocarcinoma; however, cancer risks can alter greatly between different populations that have a relatively similar $H$. pylori prevalence. ${ }^{34}$ One of the possible factors is the interaction of different $H$. pylori strains and the compound of gastric microbiota. ${ }^{4}$ The different in gastric microbiota composition between two populations within the same country with different risks of gastric cancer has been indicated in a previous study. ${ }^{4}$ They found that operational taxonomic units (OTUs) identified as Leptotrichia wadei and a genus Veillonella were greatly abundant in those with high gastric cancer risks (Túquerres town). ${ }^{4}$ Those with a lower gastric cancer risk had a high abundance of OTU's assigned to Staphylococcus, Neisseria flavescens, a member of family Porphyromonadaceae, Flavobacterium and Rothia sp. (Tumaco town). ${ }^{4}$

\section{Gastric Microbiota Compositions in Animal Studies}

Recent studies in a diverse range of animal models (mice, ${ }^{35-37}$ Mongolian gerbils, ${ }^{38,39}$ dogs $^{40}$ Eastern oysters, ${ }^{41}$ horses, ${ }^{42,43}$ and yellow catfish ${ }^{44}$ ) have reported the potential role of the gastric microbiota in different animal species. ${ }^{36,45,46}$ Several papers have reported the effect of bacterial infection on gastric mucin expression. Muc1 expression in the stomach of mice showed a decrease level in acute and chronic $H$. pylori infection. ${ }^{47}$ In Helicobacter felis-infected mice, increased Muc4 and Muc5b gene expressions were observed, while the expression of Muc5ac was unaltered or had decreased in level of expression. ${ }^{48,49}$

In germ-free INS-GAS mice the supplementation of just 3 species of commensal gastric and intestinal microbiota (ASF519 Bacteroides spp., ASF356 Clostridium spp. and ASF361 Lactobacillus murinus) in conjunction with $\mathrm{H}$. pylori infection were adequate to stimulate gastric neoplasia to the same extent as observed in mice harboring a complex microbiota. ${ }^{45}$ Significantly, these genera are enhanced in the stomach of patients with premalignant and malignant lesions. ${ }^{50}$ The contributory role to the constitution of the gastric microbiota in stimulating disease has been further supported by successfully delaying the beginning of gastric cancer in INS-GAS mice using antibiotic therapy that was undependent upon the presence of $H$. pylori. $^{50,51}$

Earlier studies have reported that the whole or individual microbiota can either contribute to noxious effects by the carcinogenic nitrosamines formation under hypochlorhydric conditions $^{52}$ or show positively influences, by decreasing the proinflammatory cytokines secretion, ${ }^{53-56}$ improving the healing of gastric ulcer, ${ }^{46,57}$ or inactivating the growth and colonization of H. pylori. ${ }^{53,58}$

The gastric microbiota has been shown to be altered by the infection of $H$. pylori in both gerbils and mice. ${ }^{36,39,59}$ Helminth infections are at higher prevalence in children infected with H. pylori and were showed to decrease the survival-time risk for gastric adenocarcinoma. ${ }^{60}$ In rodent models, co-infection with helminth did not decrease the grade of Helicobacter-caused inflammation but did delay the improvement to premalignant gastric lesions. ${ }^{60}$

The effect of Heligmosomoides polygyrus co-infection with $H$. pylori in INS-GAS mice showed that despite having similar gastric inflammation and increased levels of proinflammatory mRNA, FoxP3+ cells in the corpus increased, H. pylori-related gastric atrophy and dysplasia were decreased, and $H$. pylori-caused alterations in the gastric flora was prevented. ${ }^{60}$

\section{Conclusion}

In spite of the fact that major improvements in research techniques have been made to figure out the correlation between $H$. pylori and the gastric microbiota in the incidence of gastric cancer, ongoing and future studies should be required in welldesigned human populations. Research needs to be conducted to compare the variations of the gastric microbiota composition in uninfected and $H$. pylori-infected patients with and without different gastric diseases and to enhance the knowledge of the microbiota composition, diversity, and dynamics along with species interactions and mechanism driving/functional phyla in 
the onset and prevention of gastric diseases, including gastric cancers.

\section{References}

1. Engstrand L, Lindberg M. Helicobacter pylori and the gastric microbiota. Best Pract Res Clin Gastroenterol 2013;27(1):39-45. DOI: 10.1016/j.bpg.2013.03.016.

2. Wang $B$, Yao M, Lv L, et al. The human microbiota in health and disease. Engineering 2017;3(1):71-82. DOI: 10.1016/J.ENG.2017.01.008.

3. Walsh CJ, Guinane CM, O'Toole PW, et al. Beneficial modulation of the gut microbiota. FEBS Lett 2014;588(22):4120-4130. DOI: 10.1016/j. febslet.2014.03.035.

4. Yang I, Woltemate S, Piazuelo MB, et al. Different gastric microbiota compositions in two human populations with high and low gastric cancer risk in Colombia. Sci Rep 2016;6(18594):18594. DOI: 10.1038/ srep18594.

5. Delgado S, Cabrera-Rubio R, Mira A, et al. Microbiological survey of the human gastric ecosystem using culturing and pyrosequencing methods. Microb Ecol 2013;65(3):763-772. DOI: 10.1007/s00248-0130192-5.

6. Hooi JKY, Lai WY, Ng WK, et al. Global prevalence of Helicobacter pylori infection: systematic review and meta-analysis. Gastroenterology 2017;153(2):420-429. DOI: 10.1053/j.gastro.2017.04.022.

7. Blaser MJ. Who are we? indigenous microbes and the ecology of human diseases. EMBO Rep 2006;7(10):956-960. DOI: 10.1038/ sj.embor.7400812.

8. Herrera V, Parsonnet J. Helicobacterpyloriand gastric adenocarcinoma. Clin Microbiol Infect 2009;15(11):971-976. DOI: 10.1111/j.14690691.2009.03031.x.

9. Titov SE, Panasyuk GV, Ivanov MK, et al. Detection of Helicobacter pylori in bioptates of gastric mucosa of patients with gastritis and gastric ulcers using real-time PCR. Mol Genet Microbiol Virol 2011;26(3):126-131. DOI: 10.3103/S0891416811030074.

10. Ozbey G, Kilinc U, Ceribasi S, et al. Detection of Helicobacter pylori from gastric biopsy samples by culture, polymerase chain reaction and histopathological methods in eastern turkey. IJMCM 2012;2: $112-118$.

11. Ozbey G, Dogan Y, Demiroren K, et al. Prevalence of Helicobacter pylori in children in eastern turkey and molecular typing of isolates. Braz J Microbiol 2015;46(2):505-511. DOI: 10.1590/S1517-838246220140234.

12. Liu J, Xue Y, Zhou L. Detection of gastritis-associated pathogens by culturing of gastric juice and mucosa. Int J Clin Exp Pathol 2018;11(4):2214-2220.

13. Gantuya B, El-Serag HB, Matsumoto T, et al. Gastric microbiota in Helicobacter pylori-negative and -positive gastritis among high incidence of gastric cancer area. Cancers 2019;11(4):504. DOI: 10.3390/ cancers 11040504.

14. Hu Y, He LH, Xiao D, et al. Bacterial flora concurrent with Helicobacter pylori in the stomach of patients with upper gastrointestinal diseases. World J Gastroenterol 2012;18(11):1257-1261. DOI: 10.3748/wjg.v18. i11.1257.

15. Lagier JC, Million M, Hugon $P$, et al. Human gut microbiota: repertoire and variations. Front Cell Infect Microbiol 2012;2:136. DOI: 10.3389/ fcimb.2012.00136.

16. Adamsson I, Nord CE, Lundquist $P$, et al. Comparative effects of omeprazole, amoxycillin plus metronidazole versus omeprazole, clarithromycin plus metronidazole on the oral, gastric and intestinal microflora in Helicobacter pylori infected patients. J Antimicrob Chemother 1999;44(5):629-640. DOI: 10.1093/jac/44.5.629.

17. Savage DC. Microbial ecology of the gastrointestinal tract. Annu Rev Microbiol 1977;31(1):107-133. DOI: 10.1146/annurev. mi.31.100177.000543.

18. Bik EM, Eckburg PB, Gill SR, et al. Molecular analysis of the bacterial microbiota in the human stomach. ProcNatl Acad Sci USA 2006;103(3):732-737. DOI: 10.1073/pnas.0506655103.
19. Andersson $A F$, Lindberg $M$, Jakobsson $H$, et al. Comparative analysis of human gut microbiota by barcoded pyrosequencing. PLoS ONE 2008;3(7):e2836. DOI: 10.1371/journal.pone.0002836.

20. Dicksved J, Lindberg $M$, Rosenquist $M$, et al. Molecular characterization of the stomach microbiota in patients with gastric cancer and in controls. J Med Microbiol 2009;58(Pt 4):509-516. DOI: 10.1099/ jmm.0.007302-0.

21. Li X-X, Wong GL-H, To K-F, et al. Bacterial microbiota profiling in gastritis without Helicobacter pylori infection or non-steroidal antiinflammatory drug use. PLoS ONE 2009;4(11):e7985. DOI: 10.1371/ journal.pone.0007985.

22. Maldonado-Contreras A, Goldfarb KC, Godoy-Vitorino F, et al. Structure of the human gastric bacterial community in relation to Helicobacter pylori status. ISME J 2011;5(4):574-579. DOI: 10.1038/ ismej.2010.149.

23. Eun CS, Kim BK, Han DS, et al. Differences in gastric mucosal microbiota profiling in patients with chronic gastritis, intestinal metaplasia, and gastric cancer using pyrosequencing methods. Helicobacter 2014;19(6):407-416. DOI: 10.1111/ hel.12145.

24. Llorca L, Pérez-Pérez G, Urruzuno $P$, et al. Characterization of the gastric microbiota in a pediatric population according to Helicobacter pylori status. Pediatr Infect Dis J 2017;36(2):173-178. DOI: 10.1097/ INF.0000000000001383.

25. Cho I, Blaser MJ. The human microbiome: at the interface of health and disease. Nat Rev Genet 2012;13(4):260-270. DOI: 10.1038/nrg3182.

26. Abreu MT, Peek JrRM. Gastrointestinal malignancy and the microbiome. Gastroenterol 2014;146(6):1534-1546. DOI: 10.1053/ j.gastro.2014.01.001.

27. Li TH, Sham PK, Lau KS, et al. Alterations in gastric microbiota after H. pylori eradication and in different histological stages of gastric carcinogenesis. Sci Rep 2017;7(1):44935. DOI: 10.1038/srep44935.

28. Wroblewski LE, Peek RM,Jr, Wilson KT. Helicobacter pylori and gastric cancer: factors that modulate disease risk. Clin Microbiol Rev 2010;23(4):713-739. DOI: 10.1128/CMR.00011-10.

29. Alarcón T, Llorca L, Perez-Perez G. Impact of the microbiota and gastric disease development by Helicobacter pylori, in Molecular pathogenesis and signal transduction by Helicobacter pylori Tegtmeyer N, Backert S Cham: Springer; 2017. pp. 253-275.

30. Ottman N, Smidt H, de Vos WM, et al. The function of our microbiota: who is out there and what do they do? Front Cell Infect Microbiol 2012;2:608-616. DOI: 10.3389/fcimb.2012.00104.

31. He C, Yang Z, Lu N. Imbalance of gastrointestinal microbiota in the pathogenesis of Helicobacter pylori-associated diseases. Helicobacter 2016;21(5):337-348. DOI: 10.1111/hel.12297.

32. Zilberstein $B$, Quintanilha AG, Santos MAA, et al. Digestive tract microbiota in healthy volunteers. Clinics (Sao Paulo) 2007;62(1):47-54. DOI: 10.1590/s1807-59322007000100008.

33. Khosravi Y, Seow SW, Amoyo AA, et al. Helicobacter pylori infection can affect energy modulating hormones and body weight in germ free mice. Sci Rep 2015;5(1):8731. DOI: 10.1038/srep08731.

34. Correa P, Piazuelo M. Gastric cancer: the colombian enigma. Rev Colomb Gastroenterol 2010;25:334-337.

35. Tan MP, Kaparakis M, Galic M, et al. Chronic Helicobacter pylori infection does not significantly alter the microbiota of the murine stomach. Appl Environ Microbiol 2007;73(3):1010-1013. DOI: 10.1128/ AEM.01675-06.

36. Lofgren $\mathrm{JL}$, Whary MT, Ge Z, et al. Lack of commensal flora in Helicobacter pylori-infected INS-GAS mice reduces gastritis and delays intraepithelial neoplasia. Gastroenterology 2011;140:(1): 210-220. DOI: 10.1053/j.gastro.2010.09.048.

37. Rolig AS, Cech C, Ahler E, et al. The degree of Helicobacter pyloritriggered inflammation is manipulated by preinfection host microbiota. Infect Immun 2013;81(5):1382-1389. DOI: 10.1128/ IAI.00044-13.

38. Sun YQ, Monstein HJ, Nilsson LE, et al. Profiling and identification of eubacteria in the stomach of mongolian gerbils with and without 
Helicobacter pylori infection. Helicobacter 2003;8(2):149-157. DOI: 10.1046/j.1523-5378.2003.00136.x.

39. Osaki T, Matsuki T, Asahara T, et al. Comparative analysis of gastric bacterial microbiota in mongolian gerbils after long-term infection with Helicobacter pylori. Microb Pathog 2012;53(1):12-18. DOI: 10.1016/j.micpath.2012.03.008.

40. Garcia-Mazcorro JF, Suchodolski JS, Jones KR. Effect of the proton pump inhibitor omeprazole on the gastrointestinal bacterial microbiota of healthy dogs. FEMS Microbiol Ecol 2012;80(3):624-636. DOI: 10.1111/j.1574-6941.2012.01331.x.

41. King GM, Judd C, Kuske CR, et al. Analysis of stomach and gut microbiomes of the eastern oyster (crassostrea virginica) from coastal Louisiana, USA. PLoS ONE 2012;7(12):e51475. DOI: 10.1371/journal. pone. 0051475

42. Husted L, Jensen TK, Olsen SN, et al. Examination of equine glandular stomach lesions for bacteria, including Helicobacter spp by fluorescence in situ hybridisation. BMC Microbiol 2010;10(1):84. DOI: 10.1186/1471-2180-10-84.

43. Perkins GA, den Bakker HC, Burton AJ. Equine stomachs harbor an abundant and diverse mucosal microbiota. Appl Environ Microbiol 2012;78(8):2522-2532. DOI: 10.1128/AEM.06252-11.

44. Wu S, Tian J, Wang G, et al. Characterization of bacterial community in the stomach of yellow catfish (Pelteobagrus fulvidraco) World J Microbiol Biotechnol 2012;28(5):2165-2174. DOI: 10.1007/s11274-0121022-5.

45. Lertpiriyapong K, Whary MT, Muthupalani S, et al. Gastric colonisation with a restricted commensal microbiota replicates the promotion of neoplastic lesions by diverse intestinal microbiota in the Helicobacter pylori INS-GAS mouse model of gastric carcinogenesis. Gut 2014;63(1):54-63. DOI: 10.1136/gutjnl-2013-305178.

46. Russo F, Linsalata M, Orlando A. Probiotics against neoplastic transformation of gastric mucosa: effects on cell proliferation and polyamine metabolism. World J Gastroenterol 2014;20(37): 13258-13272. DOI: 10.3748/wjg.v20.i37.13258.

47. Navabi N, Johansson ME, Raghavan S, et al. Helicobacter pylori infection impairs the mucin production rate and turnover in the murine gastric mucosa. Infect Immun 2013;81(3):829-837. DOI: 10.1128/IAI.01000-12.

48. Schmitz JM, Durham CG, Ho SB, et al. Gastric mucus alterations associated with murine Helicobacter infection. J Histochem Cytochem 2009;57(5):457-467. DOI: 10.1369/jhc.2009. 952473.

49. Schmitz JM, Durham CG, Schoeb TR, et al. Helicobacter felis-associated gastric disease in microbiota-restricted mice. J Histochem Cytochem 2011;59(9):826-841. DOI: 10.1369/0022155411416242.
50. Noto JM, Peek RM,Jr. The gastric microbiome, its interaction with Helicobacter pylori, and its potential role in the progression to stomach cancer. PLoS Pathog 2017;13(10):e1006573. DOI: 10.1371/ journal.ppat.1006573.

51. Lee CW, Rickman B, Rogers AB, et al. Combination of sulindac and antimicrobial eradication of Helicobacter pylori prevents progression of gastric cancer in hypergastrinemic INS-GAS mice. Cancer Res 2009;69(20):8166-8174. DOI: 10.1158/0008-5472.CAN-08-3856.

52. Lundberg JO, Weitzberg E. Biology of nitrogen oxides in the gastrointestinal tract. Gut 2013;62(4):616-629. DOI: 10.1136/gutjnl2011-301649.

53. Hsieh PS, Tsai YC, Chen YC, et al. Eradication of Helicobacter pylori infection by the probiotic strains Lactobacillus johnsonii MH-68 and "L. salivarius ssp. salicinius AP-32. Helicobacter 2012;17(6):466-477. DOI: $10.1111 /$ j.1523-5378.2012.00992.x.

54. Ge Z, Feng Y, Muthupalani S, et al. Coinfection with enterohepatic Helicobacter species can ameliorate or promote Helicobacter pylori-induced gastric pathology in C57BL/6 mice. Infect Immun 2011;79(10):3861-3871. DOI: 10.1128/IAI.05357-11.

55. Lemke LB, Ge Z, Whary MT, et al. Concurrent Helicobacter bilis infection in C57BL/6 mice attenuates proinflammatory $\mathrm{H}$. pylori-induced gastric pathology. Infect Immun 2009;77(5):2147-2158. DOI: 10.1128/ IAI.01395-08.

56. Thiraworawong T, Spinler JK, Werawatganon D, et al. Antiinflammatory properties of gastric-derived lactobacillus plantarum XB7 in the context of Helicobacter pylori infection. Helicobacter 2014;19(2):144-155. DOI: 10.1111/hel.12105.

57. Dharmani P, De Simone C, Chadee K. The probiotic mixture VSL\#3 accelerates gastric ulcer healing by stimulating vascular endothelial growth factor. PLoS ONE 2013;8(3):e58671. DOI: 10.1371/journal. pone. 0058671 .

58. Delgado S, Leite AMO, Ruas-Madiedo P, et al. Probiotic and technological properties of Lactobacillus spp. strains from the human stomach in the search for potential candidates against gastric microbial dysbiosis. Front Microbiol 2015;5:766. DOI: 10.3389/ fmicb.2014.00766.

59. Arthur JC, Perez-Chanona E, Mühlbauer M, et al. Intestinal inflammation targets cancer-inducing activity of the microbiota. Science 2012;338(6103):120-123. DOI: 10.1126/science.1224820.

60. Whary MT, Muthupalani S, Ge Z, et al. Helminth co-infection in Helicobacter pylori infected INS-GAS mice attenuates gastric premalignant lesions of epithelial dysplasia and glandular atrophy and preserves colonization resistance of the stomach to lower bowel microbiota. Microbes Infect Inst Pasteur 2014;16(4):345-355. DOI: 10.1016/j.micinf.2014.01.005. 